UDC 347.82:629.7.014(045)

DOI https://doi.org/10.32838/2663-5941/2021.6/34

Ivannikova V.Yu.

National Aviation University

Ayrapetyan A.G.

National Aviation University

\title{
UNMANNED AERIAL VEHICLES (UAVS) OPERATION IN UKRAINE: A REGULATIONS REVIEW
}

Recent events in the world have given new impetus to the Unmanned Aerial Vehicles (UAVS) industry in Ukraine. Currently, their usage is growing rapidly not only in the military sphere, but in the different civilian applications such as, delivery of goods, search and rescue, urgent aerial photography, monitoring of large areas, precision agriculture, etc. Since the beginning of the COVID-19 pandemic we observe further increasing of UAVs usage in many public needs, such as tracking quarantine violators, delivery of vaccines, etc.

However, like any innovative industry, the UAVs market is facing challenges to overcome. One of them is insufficiently clear legislation, regarding the use of consumer and commercial UAVs as well as the prohibition of their free use (licensing) in the Ukrainian airspace. In addition, there is the danger of creating problems for other air traffic participants, as well as vehicles, infrastructure, and people on the ground. In turns, legal uncertainties have delayed the development of the UAVs market, which is technically ready to launch many new services.

The main issues that should be resolved in the UAVs operation regulations in Ukraine are the competence of owners and external pilots (operators) of UAVs, certification and licensing of UAVs operators; restrictions and safety of UAVS usage; UAVS registration; requirements for the use of UAVs for non-commercial and commercial purposes; the possibility of constitutional human rights violations during UAVs operation.

The paper investigates the UAVs operation regulations on the global scale and the degree of its implementation into the correspondent Ukrainian legislation.

Comparative analysis of Ukrainian legal framework and international regulations on the UAVs usage has been conducted in the article. Adapting Ukrainian regulations to the relevant requirements, standards and recommended practices of the International Civil Aviation Organization (ICAO) and the European Union (EU) is an obligation for Ukraine during its course to European integration. It has been found out in the papers that unitized Ukrainian rules, regulating the UAVS operation, are in the process of development now; they are not contradicting the correspondent $E U$ and ICAO principles as well as ensure development and necessary level of aviation safety.

It was also established in the paper that the problem of UAVs usage legislative regulation is of concern not only to Ukraine. In the majority of EU countries, the procedure for the UAVs operation has not yet been finalized.

Key words: Unmanned Aerial Vehicles, Ukraine, International Civil Aviation Organization, European Union, operation, analysis, unified regulations.

Introduction. The use of Unmanned Aerial Vehicles (hereinafter UAVs) is growing rapidly in different branches of economy, including real-time monitoring, providing wireless coverage, remote sensing, search and rescue, delivery of goods, security and surveillance, precision agriculture, civil infrastructure inspection, etc. [1-4]. So, from rush hour delivery services to scanning inaccessible areas, UAVs are proving to be critical in situations, where humans are unable to reach or cannot perform timely and efficiently hazardous tasks. Shares of the global market for the UAVs services by industry are presented in the fig. 1.

The prospect of the UAVs market is estimated as very high - in the next 3-5 years the annual sales growth will be more than $100 \%$ (see fig. 2).

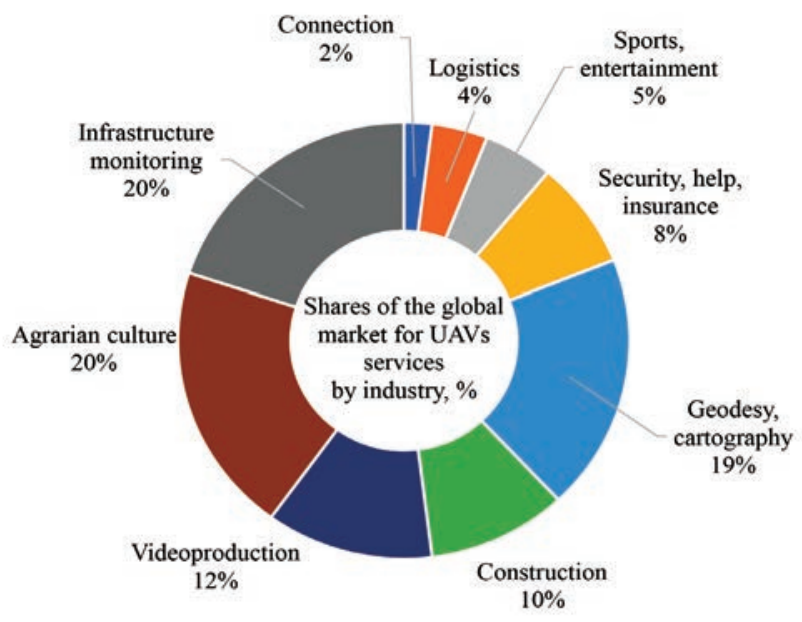

Fig. 1. Shares of the global market for the UAVs services by industry [5] 
Talking about Ukraine, key prospects for the drone market are as follows: application by the police of large cities; application by firefighters; application in healthcare; application in mapping; accurate geodata; urgent delivery of purchases, food, spare parts, batteries, cables; courier services; aerial photography for agribusiness and precision agriculture; monitoring of pipelines and power lines; use as the last mile to improve network coverage; entry into the airline UAV market; media use; increased commercial activity in software development; increased sales of drones with high-quality cameras and stabilization systems.
Since the beginning of the COVID-19 pandemic the variety of the UAV s usage is constantly increasing [7], especially, we could see the growth of their practical implementation in many public needs, such as the delivery of essential food, tracking quarantine violators, etc. [8]. Furthermore, drones have already proven to be useful tools in curbing the spread of the virus and aiding efforts to contain and battle the COVID-19 disease. There are in fact at least five tangible ways, in which the UAVs can and are being used right now in the period of Coronavirus Crisis (see fig. 3).
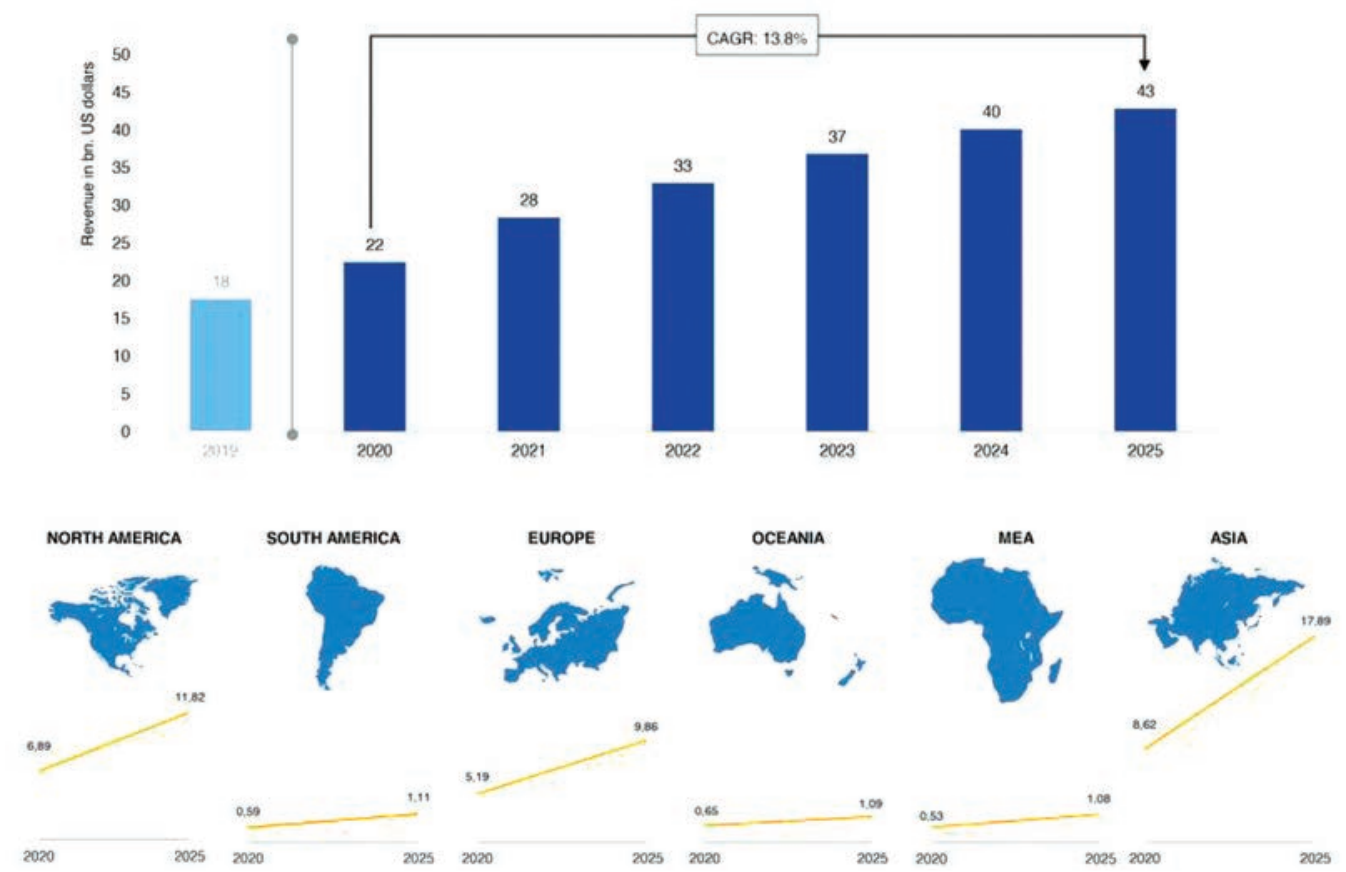

Fig. 2. Scheme on the drone market size and forecast 2020-2025 [6]
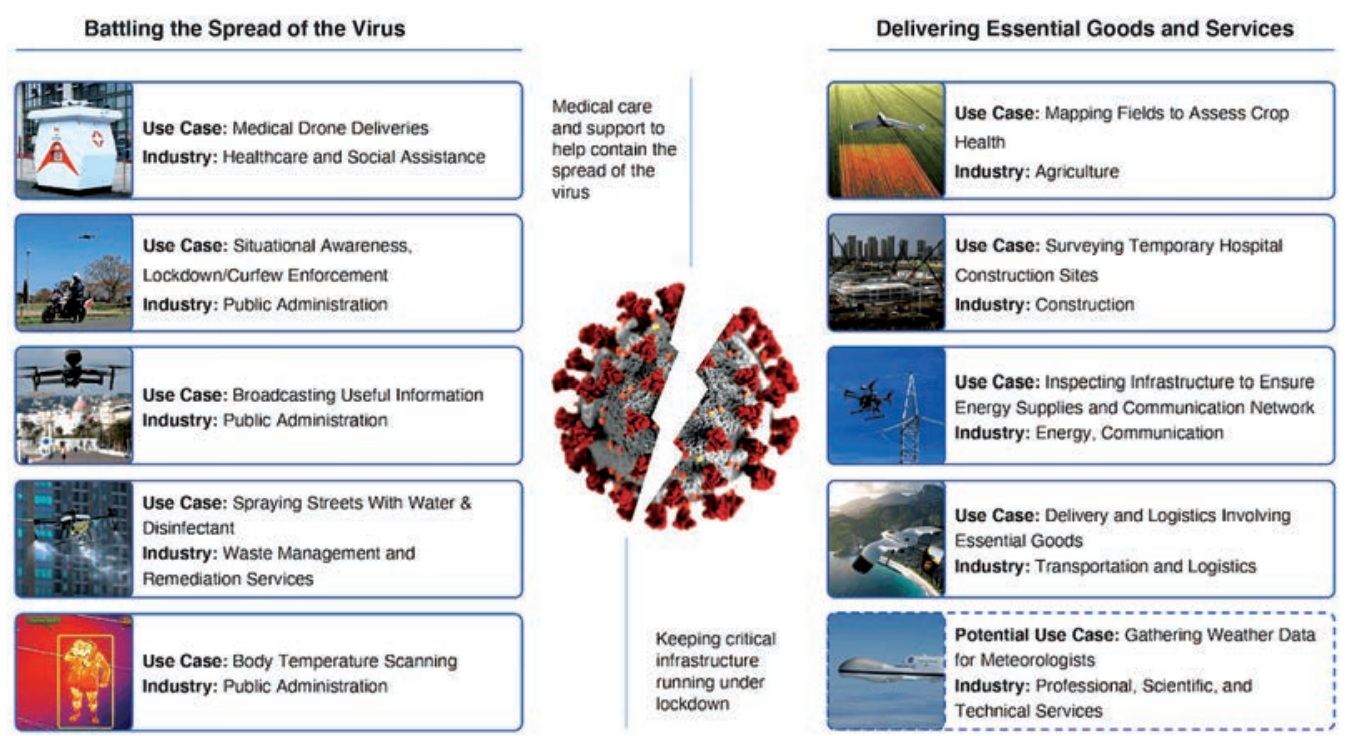

Fig. 3. Main areas of UAVs application in the coronavirus crisis [8] 
However, like any innovative industry, the UAVs market is facing challenges to overcome. One of them is insufficiently clear legislation, regarding the use of consumer and commercial UAVs as well as the prohibition of their free use (licensing) in the airspace of Ukraine. In addition, there is the danger of creating problems for other air traffic participants, as well as vehicles, infrastructure, and people on the ground. There are serious concerns about the misuse of drones for interference with privacy and commercial confidentiality, and about the possibility of others intercepting and gaining control of the UAVs.

So, Ukraine has begun to use the technology of the UAVs rather quickly in recent years, while the legal framework that regulates their application still requires improvement.

Literature Review. Regulations of the UAVs usage are actively investigated by foreign and domestic scientists. The first holistic global overview of the current status of UAVs regulations in the world was done by Claudia Stöcker et. al., 2017 [9]. Comparative analysis of existing national and international drone laws with emphasis on the registration of aircraft and important guidelines in regard to the qualification and license for pilots was done by the Indian scientists Srivastava S. et. al., 2020 [10]. System-theoretic Accident Model and Process approach to assess the current regulations of the UAVs operation was done by Japanese scientists Hiroko Nakamura and Yuya Kajikawa, who focused their researches on the regulation of small unmanned aerial vehicles operation in Japan. The authors highlight four safety concerns and show alternative ways for more effective and efficient regulation in terms of the expectations of stakeholders for alternative regulation [11]. Safety and security issues with drones, existing regulations and guidelines to fly

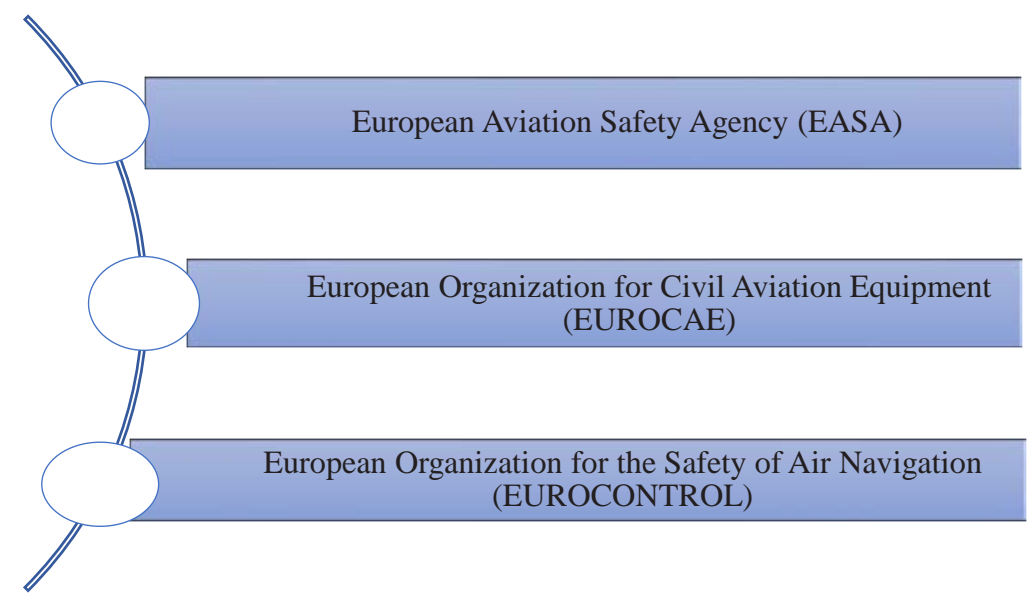

Fig. 4. International institutions, developing air legislation in the field of UAVs operation the drone, limitations and possible solutions have also been discussed by Singhal, G. et. al., 2018 [3].

Talking about Ukrainian scientists, working in the sphere of the UAVs operation regulations, it should be mentioned such researchers as Khalymon, S., Hrynko, S., Zolka, V., Hrynko, R., Volynets, N., Kuzmenko, Ye., Bakutin Ye.I., Kovtukh N.P. etc. Serhii Khalymon, et el. has tried to develop propositions for the improvement of regulations, used during UAVs usage in surveillance of the state border of Ukraine [12]. Problems of legal regulation of UAVs usage in the activities of the National Police of Ukraine have been considered in the papers of Kuzmenko Ye.V. and Bakutin Ye.I. [13; 14]. Kovtukh N.P. analysed in his paper European Union (EU) regulations for the UAVs operation, used up to 2019 [15].

However, all these researchers analyzed only some aspects of the UAVs usage and didn't investigate the correspondence of the current Ukrainian rules, regulating UAVs operation, to the relevant requirements, standards and recommended practices of the International Civil Aviation Organization (ICAO) and the EU.

Problem statement. Due to the fact that now there is an irreversible process of technological development, the issues that arise with the regulation of the UAVs usage are becoming increasingly relevant. The main problems that should be resolved in the uniform UAVs operation rules at our country are the competence of owners and external pilots (operators) of UAVs, the scope of their use, certification and licensing, restrictions in use, safety of their use, which concerns the surrounding space, the definition of zones, in which you can use UAVs, UAVs registration, requirements for the use of UAVs for non-commercial and commercial purposes, the possibility of violations of constitutional human rights (for example, such as the right to privacy, which is guaranteed by the Article 32 of the Constitution of Ukraine).

Such legislation should cover all types of operations, from those for which no prior authorization is required, to those involving certified aircraft and operators, as well as minimum training requirements for outside pilots.

That's why, aim of the article - to analyze the latest international and domestic rules, regulating the UAVs operation, and investigate the degree of the ICAO and EU requirements, standards and recommended practices in this field implementation into the correspondent Ukrainian legislation. 
Implementation of the EU and ICAO rules and standards on the use of UAVs will certainly contribute to the successful entry of our state into the European airspace and economy.

Materials and Methods. International institutions, developing air legislation in the field of UAVs operation are presented in the fig. 4.

Analyzing the European Union system for regulating the flight of drones, it has been established that up to 2019 it was based on fragmentary rules of member states. In 2014, the European Commission developed a strategy to open the aviation market to civilian use of Remotely Piloted Aircraft Systems (RPAS) in a safe way. That's why, in 2014, most experts leaned in favor of creating a unified European approach, based on national experience. At that time, many countries have adopted rules for some aspects of UAVs use with a working mass of up to $150 \mathrm{~kg}$. However, these rules vary in scope, level of detail, and content. At the same time the participating countries have not reached an agreement on the recognition of uniform rules [4, p. 8, 9].

On July 4, 2018 the European Union Regulation on common rules in the field of civil aviation and the creation of the European Union Aviation Safety Agency was adopted, which contributed to the development of the current EU regulations on the UAVs operation, presented on the fig. 5 .

The latest EU regulations, shown on the fig. 5, are based on the national legislation and were created to unify the rules for the use of UAVs within EU. Such categories of flights, as open, special and certified, have been appeared in the regulations. Also, every drone that weighs more than $250 \mathrm{~g}$ and performs operations with video fixing equipment must be registered, despite the category, because of the risks, associated with the violation of privacy principles [17].

When adapting Ukrainian legislation to the EU documents, considered above, the attention should be paid to the precedents of the European Court of Justice. Currently, the court has determined that "activities carried out in the course of the personal or family life of individuals, clearly not related to the processing of personal data, which consists in publishing on the Internet in such a way that this information is available to an unlimited number of people" is surveillance and a violation of the right to privacy [19].

On the other hand, relevant for Ukraine, the European Court of Human Rights confirmed that "the area of interaction of an individual with others, even in a public context, which may fall under the definition of privacy" would not be defined as surveillance [20].

A regulatory framework for the UAVs control is expected to be presented by EU in the nearest future. The approach adopted by the Commission and supported by the EASA, is to apply the safety standards, achieved in manned aviation to drones. The rules are based on an operational risk assessment and balance the commitments of drone manufacturers and operators to safety, privacy, environmental and noise protection, etc.

Adapting Ukrainian regulations to the relevant requirements, standards and recommended practices of the ICAO and the EU is an obligation for Ukraine during its course of European integration.

That's why, in August 2016 the State Aviation Administration of Ukraine prepared draft unified guidelines and recommendations on the use of UAVs [21]. These regulations have been developed on the bases of the EASA guidelines [22] and national aviation rules as follows: The Air Code of Ukraine [23]; Provisions on the Use of the Airspace of Ukraine [24]; Rules of Ukrainian airspace usage [25].

The Air Code of Ukraine clearly defines what UAV is. According to the Part 23, Article 1 of the Air Code of Ukraine "Unmanned Aerial Vehicle" is an aircraft designed to fly without a pilot on board, the flight control and monitoring of which is carried out by a special control station, located outside the aircraft [23].

The draft unified regulations determine the rights and limitations for the UAVs operators. For example, drone operators are encouraged to respect privacy by keeping a distance of 50 meters away from people and property, avoid flights of over 100 meters, be aware of security provisions, complete pre-flight inspection

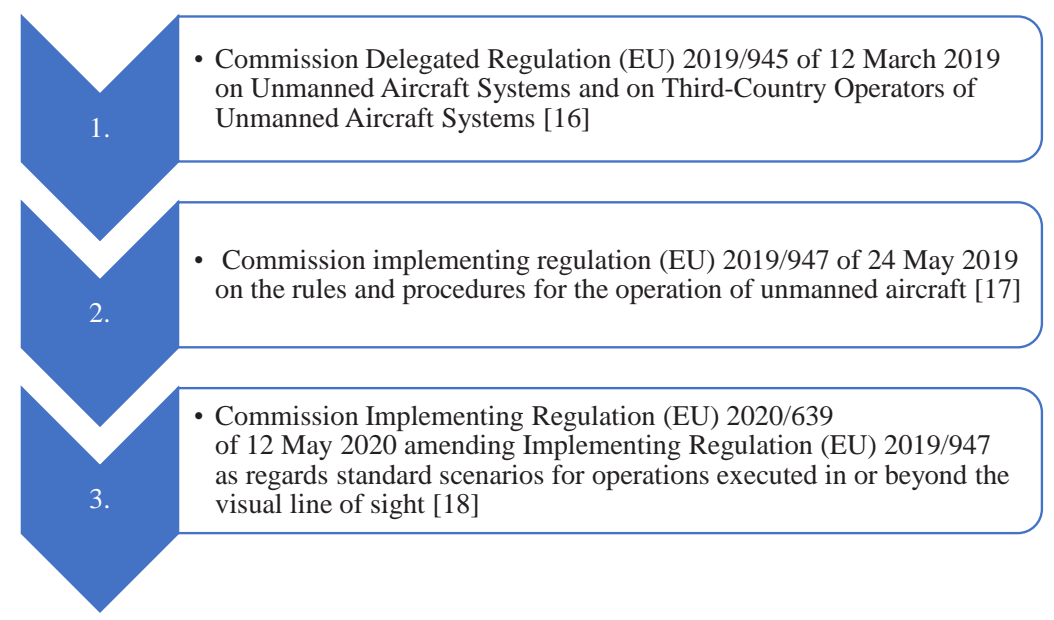

Fig. 5. Current EU regulations on the UAVs operation 
of UAVs, keep UAVs within visual range at all times, and refrain from flying in bad weather conditions.

Additionally, the UAVs are not allowed within 5 kilometers of airports, restricted areas, or dangerous areas; to fly above vehicles, city streets, or crowds; or to be affixed with any additional items that are not part of the original design.

However, these rules are only recommendations and, therefore, not enforceable. Taking into account current international practices, these conditions will likely be used as the basis for the new legislation being drafted at this moment.

Ukrainian State Aviation Service proposed four UAVs classifications in the correspondent draft recommendations, shown in the fig. 6 .

These kinds of drones are quite common around the world today.

Currently, Ukrainian State Aviation Service presented a uniform UAVs regulations draft for public discussion. After the detailed analysis, it has been found out that this document is in full correspondence with the EU principles, regulating UAVs operation, and provides necessary level of aviation safety.

The process for the correspondent regulations implementation was affected by two significant

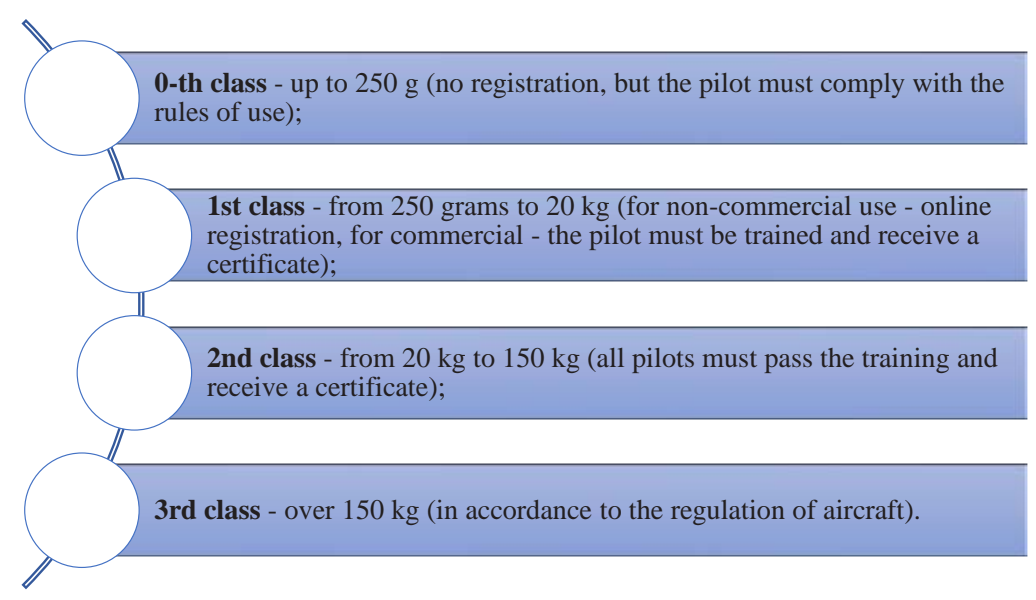

Fig. 6. Classification of UAVs, proposed by the Ukrainian State Aviation Service [24] factors. First, Ukraine did not have to contend with an overwhelming majority of uncontrolled drones, like in the United States (U.S.), therefore, progress in establishing modern regulations for drones was not considered urgent. At the same time, military conflict in the east and the needs of the agriculture industry, placed pressure on legislators to come up with good regulations for the use of drones.

Conclusions. To summarize, the legislation of Ukraine should be in constant dynamics and comply with international legal acts in the field of aviation and the latest technologies, especially, today during its course to European integration. Currently, the unitized Ukrainian rules, regulating the UAVs operation are in the process of development. It has been established that these draft rules don't contradict the correspondent EU principles as well as ensure development and necessary level of aviation safety.

It should be also noted that the problem of legislative regulation of the use of drones is of concern not only to Ukraine. In the majority of EU countries, the procedure for the UAVs operation has not yet been finalized. The most advanced in this respect is the USA, where small drones can fly relatively freely at altitudes of up to 400 meters. Nevertheless, even in the USA, the issues of safe use of drones remain open, especially, the use of drones in densely populated areas and over urban areas. Legal uncertainties have delayed the development of the UAVs market, which is technically ready to launch many new services, such as delivery of goods, urgent aerial photography, monitoring of large areas, etc.

Finally, the unified regulations, adopted by the EU in 2020 will now greatly simplify access to unmanned operations, regardless of which European country you plan to operate in.

\section{References:}

1. Hayat, E. Yanmaz, R. Muzaffar. Survey on unmanned aerial vehicle networks for civil applications: A communications viewpoint. IEEECommun. Surveys Tuts. 2016. vol. 18. № 4. P. 262-266.

2. Starodub, Yu. P., \& Havrys, A. P. Increasing areas security project for the risk flooding territories of Ukraine. Central European Journal for Science and Research "Stredoevropsky Vestnik pro vedu a vyzkum”. Praha, 2015. P. 42-46.

3. Singhal, G., Bansod, B., Mathew, L. Unmanned Aerial Vehicle Classification, Applications and Challenges: A Review. Preprints. 2018, 2018110601 (doi: 10.20944/preprints201811.0601.v1).

4. Yudin O., Ziubina R., Buchyk S., Matviichuk-Yudina O., Suprun O. Ivannikova V. Development of methods for identification of information-controlling signals of unmanned aircraft complex operator. EasternEuropean Journal of Enterprise Technologies ISSN 1729-3774. 2020. №2/9 (104). C. 56-72. 
5. World experience in legal regulation of drones' usage. European Information and Research Center, 2021.

URL: http://euinfocenter.rada.gov.ua/uploads/documents/28939.pdf (Accessed 01.11.2021).

6. Drone market size and forecast 2020-2025. Drone Industry Insights, 2020. URL: https://droneii.com (Accessed 01.11.2021).

7. Ivannikova V.Yu., Korynevska T.B. Investigation of COVID-19 influence on the airline industy. Інноваційні технології: наук.-техн. конф. студентів, аспірантів, докторантів та молодих учених, 25-26 листоп. 2020 р.: тези доп. Київ, 2020. С. 334-338.

8. Drones and the Coronavirus: From Crisis to Opportunity. Drone Industry Insights, 2020. URL: https://droneii.com/drones-and-the-coronavirus-from-crisis-to-opportunity? fbclid=IwAR2TXiISOK_ BADFigGea_YVdnNdRFES14eBea3fHGxU862qRA40tjR1 Wyc (Accessed 05.11.2021).

9. Claudia Stöcker, Rohan Bennett, Francesco Nex, Markus Gerke, Jaap Zevenbergen. Review of the Current State of UAV Regulations. Remote Sens. 2017. 9(5):495. https://doi.org/10.3390/rs9050459

10. Srivastava S., Gupta S., Dikshit O., Nair S. A Review of UAV Regulations and Policies in India. In: Jain K., Khoshelham K., Zhu X., Tiwari A. Proceedings of UASG 2019. UASG 2019. Lecture Notes in Civil Engineering. Springer, 2020. vol 51. https://doi.org/10.1007/978-3-030-37393-1_27

11. Hiroko Nakamura, Yuya Kajikawa. Regulation and innovation: How should small unmanned aerial vehicles be regulated? Technological Forecasting and Social Change . 2018. Volume 128. P. 262-274.

12. Khalymon, S., Hrynko, S., Zolka, V., Hrynko, R., Volynets, N. Legal regulation of unmanned aerial vehicles application in the surveillance of the state border of Ukraine. Amazonia Investiga. 2021. Volume 10 (40). P. 190-200. https://doi.org/10.34069/AI/2021.40.04.19

13. Kuzmenko, Ye. V. Problems of legal regulation of unmanned aerial vehicles application in law enforcement activities of the National Police of Ukraine. Scientific Bulletin of the National Academy of Internal Affairs. 2016. № 4. P. 82-89.

14. Бакутін Є.I. Напрями вдосконалення законодавчого регулювання використання безпілотних літальних апаратів (БПЛА) в діяльності Національної поліції України. Держава і право: зб. наук. пращь. Юрид. $i$ політ. науки. 2017. Вип. 77. С. 307-320.

15. Ковтюх Н.П., Адміністративно-правове регулювання використання безпілотних літальних апаратів у Європейському Союзі. Актуальні проблеми вітчизняної юриспруденції. 2019. № 3. С. 87-90.

16. Commission Delegated Regulation (EU) 2019/945 on unmanned aircraft systems and on thirdcountry operators of unmanned aircraft systems, 2019. URL: https://eur-lex.europa.eu/legal-content/EN/ TXT/?uri=CELEX:32019R0945 (Accessed 01.11.2021).

17. Commission Implementing Regulation (EU) 2019/947, 2019. URL: https://www.easa.europa.eu/documentlibrary/regulations/commission-implementing-regulation-eu-2019947 (Accessed 01.11.2021).

18. Commission Implementing Regulation (EU) 2020/639, 2020. URL: https://www.easa.europa.eu/documentlibrary/regulations/commission-implementing-regulation-eu-2020639 (Accessed 01.11.2021).

19. Document 62013CJ021. Judgment of the Court (Fourth Chamber)., 2014. URL: https://eur-lex.europa.eu/ legal-content/EN/TXT/?uri=CELEX\%3A62013CJ0212 (Accessed 05.11.2021).

20. European Convention on Human Rights. Right to respect for private and family life, home and correspondence, 2020. URL: https://www.echr.coe.int/documents/guide_art 8 eng.pdf (Accessed 05.11.2021).

21. Unmanned Aerial Vehicles Norms of Regulation. Air Service of Ukraine, 2021. URL: https://avia.gov.ua/ bezpilotni-povitryani-sudna-2/ (Accessed 15.11.2021).

22. Recommendations on the use of drones. EASA, 2021. URL: Access mode to the resource: https://www.easa.europa.eu/domains/civil-drones-rpas (Accessed 15.11.2021).

23. The Air Code of Ukraine, 2017. URL: https://zakon.rada.gov.ua/laws/show/3393-17\#Text (Accessed 01.11.2021).

24. Provisions on the Use of the Airspace of Ukraine, 2017. URL: https://zakon.rada.gov.ua/laws/ show/954-2017-\%D0\%BF\#Text (Accessed 01.11.2021).

25. Rules of Ukrainian airspace usage, 2018. URL: https://zakon.rada.gov.ua/laws/show/z1056-18\#Text (Accessed 01.11.2021).

\section{Іваннікова В.Ю., Айрапетян А.Г. ЕКСПЛУАТАЦІЯ БЕЗПІЛОТНИХ ЛІТАЛЬНИХ АПАРАТІВ В УКРАЇНІ: ОГЛЯД НОРМАТИВНО-ЗАКОНОДАВЧОЇ БАЗИ}

Останні події у світі дали новий поштовх розвитку безпілотних літальних апаратів (БПЛА) в Україні. Сьогодні вони широко використовуються не лише у військовій сфері, а й у різних циивільних галузях, як-от доставка вантажів, пошуково-рятувальні роботи, термінова аерофотозйомка, моніторинг великих територій, сільське господарство тощо. Із початку пандемії COVID-19 ми спостерігаємо подальше збільшення використання БПЛА у багатьох изивільних потребах, як-от відстеження порушників карантину, доставка вакцин тощчо. 
Як $і$ будь-яка інноваційна галузь, ринок БПЛА зіткнувся із викликами, які необхідно подолати. Одним із таких викликів є недостатньо чітке законодавство щџдо експлуатачї̈ некомерційних та комериійних БПЛА, а також заборона їх вільного використання (лічензування) в повітряному просторі України. Крім того, існує небезпека створення проблем для інших учасників повітряного руху, а також транспортних засобів, інфраструктури та людей на землі. Юридична невизначеність затримала розвиток ринку БПЛА, який технічно готовий запустити багато нових послуг.

Основними питаннями, які повинні бути вирішені в нормативно-правових документах, щодо експлуатації БПЛА в Україні є компетентність власників та зовнішніх пілотів (операторів) БПЛА, сертифікаиія та лічензування операторів БПЛА; обмеження та безпека використання БПЛА; реєстраиія БПЛА; вимоги до використання БПЛА в некомериійних і комериійних иіілях; можсливість порушення конститучійних прав людини під час експлуатаиії БПЛА.

У статті досліджено нормативно-правову базу, яка регулює експлуатачію БПЛА у світовому маситабі та ступінь ї̈ імплементації у відповідне законодавство України. Проведено порівняльний аналіз законодавства Украӥни та міжнародних нормативно-правових актів щзодо використання БПЛА. Адаптаиія законодавства України до відповідних вимог, стандартів та рекомендованих практик Міжнародної організаиії цивільної авіаиії (ICAO) та Європейського Союзу (ЕС) є обов'язковою умовою для України на шляху ї̈ європейської інтеграції. У роботі з 'ясовано, щзо уніфіковані українські правила, які регулюють експлуатацію БПЛА, зараз перебувають на стадії обговорення, вони не суперечать відповідним принциипам СС та ICAO, а також забезпечують розвиток і необхідний рівень авіаційної безпеки. У статті також установлено, що проблема законодавчого регулювання використання БПЛА актуальна не лише для України, а й для більшості країн ЄС, де прочедура експлуатації БПЛА ще також не завершена.

Ключові слова: безпілотні літальні апарати, Україна, Міжнародна організація цивільної авіації, Європейський Союз, експлуатація, аналіз, уніфіковані правила. 